\title{
Comment on 'The incidence of leukaemia in women with BRCA1 and BRCA2 mutations: an International Prospective Cohort Study'
}

\author{
Bernard Friedenson*,1 \\ ${ }^{1}$ Department of Biochemistry and Molecular Genetics, University of Illinois at Chicago, Chicago, IL, USA
}

Sir,

It is important to identify breast cancer patients at undue risk for leukaemia associated with breast cancer chemotherapy to measure risks $v s$ benefits of chemotherapy. Iqbal et al (2016) conclude that although leukaemia in BRCA2 carriers is primarily caused by breast cancer chemotherapy, it is so rare that BRCA mutation carriers can be treated according to standard protocols. However there are multiple confounders in determining risks; and leukaemia in breast cancer patients can be caused by biological factors that go beyond chemotherapy.

All patients with leukaemia had breast cancer in the study (Iqbal et al, 2016) but they all had different BRCA1 or BRCA2 mutations. Three breast cancer patients with leukaemia had deletions that cause major disruption in the activity of the BRCA1 or BRCA2 gene. Two of the three died. Complete inactivation of the BRCA2 gene occurs by germline mutations in some children. Of seven children with biallelic BRCA2 (FANCD1) mutations, at least five were diagnosed with childhood leukaemia before age 6 (Wagner et al, 2004). All six children with a mutation in IVS7 of the BRCA2 gene were diagnosed with leukaemia before age 3 (Alter, 2014). In a larger sample of 36 patients, 17 patients developed leukaemia, mostly acute myeloid leukaemias (AML) (Alter, 2014).

A total of 18 Fanconi anaemia proteins participate in pathways containing BRCA1 and BRCA2, and hereditary defects in some of the Fanconi proteins associate with very high risks for leukaemia (e.g. $20 \%$ by age 40) (Alter, 2014). Meta-analyses found the combined relative risks (confidence intervals) that a Fanconi anaemia patient will develop: AML as 703 (364-1355); leukaemia before age 15 as 170.3 (96.5-300.5); and the precancerous condition myelodysplastic syndrome as over 17000 (Friedenson, 2007). These results show that BRCA1 and BRCA2 pathways are essential to prevent haematopoietic cancers.

The study cohort (Iqbal et al, 2016) was inadvertently selected for the ability to survive their mutation so the BRCA mutation carriers who participated were less likely to have mutations and environment factors serious enough to predispose to either breast cancer or leukaemia. In fact, $56 \%$ of the mutation carriers (4040 out of 7243) did not have breast cancer. As the authors note, $30 \%$ of the study group was lost to follow-up (Iqbal et al, 2016) and may include those most likely to have died from breast cancer or leukaemia.

Elevated leukaemia risks were not found for BRCA1 mutation carriers (Iqbal et al, 2016), but chemotherapy is known to interfere with BRCA1 expression by inactivating the gene promoter (Scardocci et al, 2006). Most primary AML cell lines have low BRCA1 expression (Faraoni et al, 2015). Among 47 survivors of breast cancer who developed leukaemia attributed to therapy, mutations in BRCA1 exceeded mutations in BRCA2 (6\% vs 4\%) (Churpek et al, 2016). From 1975 to 1978, chemotherapy meant melphalan or mechlorethamine, but later treatment used cyclophosphamide, which is less likely associated with AML (Curtis et al, 1992). Therefore, differences in treatment protocols (Iqbal et al, 2016) and the dates of treatment are potential confounders.

The length of follow-up time after chemotherapy ranged from 1.0-19.5 years (Iqbal et al, 2016). The standardised incidence ratio (SIR) for AML $\geqslant 10$ years. after breast cancer chemotherapy is about the same as in the general population in SEER registries: SIR $=1.53(0.97-2.29)$ (Morton et al, 2013). The risk of AML at 1-4.9 years after chemotherapy for unselected patients is similar to SIR values for BRCA2 carriers: SIR $=8.6$ (7.32-10.05) (Morton et al, 2013) vs $\mathrm{SIR}=8.11 \quad(2.06-22.07)$ (Iqbal et al, 2016), respectively. Breast cancer stage and ethnic groups are further potential confusing factors. Non-Hispanic white women and Hispanic women with stage I breast cancer have leukaemia risks after chemotherapy similar to a control population (Calip et al, 2015). Black women and Pacific Islanders with stage III breast cancer have leukaemia risks after chemotherapy (Calip et al, 2015) that are similar to those reported for BRCA2 mutation carriers (Iqbal et al, 2016).

Despite such potential alternate explanations, direct genomic and structural evidence supports the idea that leukaemias and other immune system cancers have associations with breast cancer that go beyond chemotherapy. Myeloid cells (macrophages) can constitute over half the mass of cells in some breast cancers (Lewis and Pollard, 2006), so mutations found in myeloid leukaemias are also found in breast cancers. T-cell leukaemias caused by the known leukaemia/lymphoma virus HTLV-1 (Kataoka et al, 2015) were compared with a reference set of breast cancers (Banerji et al, 2012), and showed that 35\% (104 out of 301) of exome genes mutated in leukaemias are also mutated in breast cancers. Genes mutated in the same breast cancer genomes (Banerji et al, 2012) were also compared with genes recurrently mutated in eight genomes from primary AML. In AML, 28 different genes are recurrently mutated and presumably linked to AML pathogenesis (Ding et al, 2012). Nine (32\%) of the 28 genes are also mutated in the reference breast cancers but the similarities extended further, suggesting an even stronger relationship. For example, WAC and DCLK1 were recurrently mutated genes associated with AML relapse (Ding et al, 2012) and were also mutated in some breast cancer genomes. Genes with functions similar to at least another 7 out of $28(25 \%)$ additional recurrently mutated AML genes were also mutated in the breast cancers. Most breast cancer mutations occurred in genes with some connection to infection and immunity (Friedenson, 2015). At least 58 mutated genes were specifically related to leukaemias, including six multi-lineage leukaemia genes. Three of eight genes (37.5\%) recurrently mutated in acute promyelocytic leukaemia were mutated in breast cancers (STAG2, SMC1A and MYCBP2) (Ibanez et al, 2016).

Convincing evidence associates human papilloma virus (HPV) (Glenn et al, 2012; Simoes et al, 2012) with some breast cancers. Genes that encode for pathways mediated by BRCA1, BRCA2 and Fanconi anaemia gene products are essential for immunity to clear HPV infection and to prevent replication of this dangerous pathogen (Hoskins et al, 2012). High percentages of genes damaged by mutation in BRCA1- and BRCA2-associated breast cancer involve immune responses or other protective functions (Friedenson, 2013; Friedenson, 2014; Friedenson, 2015). Human papilloma viruses interfere with multiple immuneassociated responses (Lee et al, 2006; Deligeoroglou et al, 2013; Iijima et al, 2013; Sanchez-Reyes et al, 2014; Tummers and Burg, 2015) and cause major chromosome aberrations in human peripheral blood lymphocytes (Paz-y-Mino et al, 1992; Alvarez-Rosero et al, 2008). Human papilloma viruses are the established cause of cervical cancer. Chemotherapy given for cervical cancer in the presence of HPV infection increases leukaemia risk close to the level reported in BRCA2-associated breast cancers: $\operatorname{SIR}=7.29$ (2.67-15.86) (Morton et al, 2013)

Macrophages then lymphocytes have been implicated as essential first and second intermediates, respectively, in breast infection by some viruses that have been associated with breast cancers. Immune cells become reservoirs that deliver such cancer-associated infections to the breast (Domenech et al, 2000; Zur Hausen, 2009; Holland and Pogo, 2012). Breast duct structures reveal integrated resident cells from the immune system (Degnim et al, 2014; Gulbahce et al, 2014) and breast cancers contain infiltrates with large numbers of macrophages and lymphocytes. Cancer or tumour virus infection of proliferating resident or infiltrated cells from the immune system can quickly spread to the breast and vice versa. There are clinical examples consistent with this explanation, for example, (Etkind et al, 2000; Salagovic et al, 2012).

Although a connection between BRCA mutations and leukaemia/ lymphoma may cause concern in women who carry BRCA mutations, their cancers are not inevitable (Levin et al, 2012) and this connection may at last help us begin to understand and address the root causes of breast cancer.

\section{ACKNOWLEDGEMENTS}

I am grateful for support from the University of Illinois at Chicago.

\section{CONFLICT OF INTEREST}

The author declares no conflict of interest. 
REFERENCES

Alter BP (2014) Fanconi anemia and the development of leukemia. Best Pract Res Clin Haematol 27(3-4): 214-221.

Alvarez-Rosero RE, Rodriguez-Argote J, Arboleda-Moreno YY, Munoz-Benitez SL, Sierra-Torres CH (2008) Chromosome aberrations in peripheral blood lymphocytes of high-risk HPV-infected women with HGSIL. Environ Mol Mutagen 49(9): 688-694.

Banerii S, Cibulskis K, Rangel-Escareno C, Brown KK, Carter SL, Frederick AM, Lawrence MS, Sivachenko AY, Sougnez C, Zou L, Cortes ML, FernandezLopez JC, Peng S, Ardlie KG, Auclair D, Bautista-Pina V, Duke F, Francis J, Jung J, Maffuz-Aziz A, Onofrio RC, Parkin M, Pho NH, Quintanar-Jurado V, Ramos AH, Rebollar-Vega R, Rodriguez-Cuevas S, Romero-Cordoba SL, Schumacher SE, Stransky N, Thompson KM, Uribe-Figueroa L, Baselga J, Beroukhim R, Polyak K, Sgroi DC, Richardson AL, Jimenez-Sanchez G, Lander ES, Gabriel SB, Garraway LA, Golub TR, Melendez-Zajgla J, Toker A, Getz G, Hidalgo-Miranda A, Meyerson M (2012) Sequence analysis of mutations and translocations across breast cancer subtypes. Nature 486(7403): 405-409.

Calip GS, Law EH, Ko NY (2015) Racial and ethnic differences in risk of second primary cancers among breast cancer survivors. Breast Cancer Res Treat 151(3): 687-696.

Churpek JE, Marquez R, Neistadt B, Claussen K, Lee MK, Churpek MM, Huo D, Weiner H, Bannerjee M, Godley LA, Le Beau MM, Pritchard CC, Walsh T, King MC, Olopade OI, Larson RA (2016) Inherited mutations in cancer susceptibility genes are common among survivors of breast cancer who develop therapy-related leukemia. Cancer 122(2): 304-311.

Curtis RE, Boice Jr. JD, Stovall M, Bernstein L, Greenberg RS, Flannery JT, Schwartz AG, Weyer P, Moloney WC, Hoover RN (1992) Risk of leukemia after chemotherapy and radiation treatment for breast cancer. $N$ Engl J Med 326(26): 1745-1751.

Degnim AC, Brahmbhatt RD, Radisky DC, Hoskin TL, Stallings-Mann M, Laudenschlager M, Mansfield A, Frost MH, Murphy L, Knutson K, Visscher DW (2014) Immune cell quantitation in normal breast tissue lobules with and without lobulitis. Breast Cancer Res Treat 144(3): 539-549.

Deligeoroglou E, Giannouli A, Athanasopoulos N, Karountzos V, Vatopoulou A, Dimopoulos K, Creatsas G (2013) HPV infection: immunological aspects and their utility in future therapy. Infect Dis Obstet Gynecol 2013: 540850.

Ding L, Ley TJ, Larson DE, Miller CA, Koboldt DC, Welch JS, Ritchey JK, Young MA, Lamprecht T, McLellan MD, McMichael JF, Wallis JW, Lu C, Shen D, Harris CC, Dooling DJ, Fulton RS, Fulton LL, Chen K, Schmidt H, Kalicki-Veizer J, Magrini VI, Cook L, McGrath SD, Vickery TL, Wendl MC, Heath S, Watson MA, Link DC, Tomasson MH, Shannon WD, Payton JE, Kulkarni S, Westervelt P, Walter MJ, Graubert TA, Mardis ER, Wilson RK, DiPersio JF (2012) Clonal evolution in relapsed acute myeloid leukaemia revealed by whole-genome sequencing. Nature 481(7382): 506-510.

Domenech A, Goyache J, Llames L, Jesus Paya M, Suarez G, Gomez-Lucia E (2000) In vitro infection of cells of the monocytic/macrophage lineage with bovine leukaemia virus. J Gen Virol 81(Pt 1): 109-118.

Etkind P, Du J, Khan A, Pillitteri J, Wiernik PH (2000) Mouse mammary tumor virus-like ENV gene sequences in human breast tumors and in a lymphoma of a breast cancer patient. Clin Cancer Res 6(4): 1273-1278.

Faraoni I, Compagnone M, Lavorgna S, Angelini DF, Cencioni MT, Piras E, Panetta P, Ottone T, Dolci S, Venditti A, Graziani G, Lo-Coco F (2015) BRCA1, PARP1 and gammaH2AX in acute myeloid leukemia: role as biomarkers of response to the PARP inhibitor olaparib. Biochim Biophys Acta 1852(3): 462-472.

Friedenson B (2007) The BRCA1/2 pathway prevents hematologic cancers in addition to breast and ovarian cancers. BMC Cancer 7: 152.

Friedenson B (2013) Mutations in components of antiviral or microbial defense as a basis for breast cancer. Funct Integr Genomics 13(4): 411-424.

Friedenson B (2014) Many breast cancer mutations parallel mutations in known viral cancers. J Genomes Exomes 3: 17-35.

Friedenson B (2015) Mutations in breast cancer exome sequences predict susceptibility to infections and converge on the same signaling pathways. I Genomes Exomes 4: 1-28.

Glenn WK, Heng B, Delprado W, Iacopetta B, Whitaker NJ, Lawson JS (2012) Epstein-Barr virus, human papillomavirus and mouse mammary tumour virus as multiple viruses in breast cancer. PLoS One 7(11): e48788.

Gulbahce HE, Vanderwerf S, Blair C, Sweeney C (2014) Lobulitis in nonneoplastic breast tissue from breast cancer patients: association with phenotypes that are common in hereditary breast cancer. Hum Pathol 45(1): 78-84.

Holland JF, Pogo BG (2012) Comment on the review by Joshi and Buehring. Breast Cancer Res Treat 136(1): 303-307.
Hoskins EE, Morreale RJ, Werner SP, Higginbotham JM, Laimins LA, Lambert PF, Brown DR, Gillison ML, Nuovo GJ, Witte DP, Kim MO, Davies SM, Mehta PA, Butsch Kovacic M, Wikenheiser-Brokamp KA, Wells SI (2012) The fanconi anemia pathway limits human papillomavirus replication. J Virol 86(15): 8131-8138.

Ibanez M, Carbonell-Caballero J, Garcia-Alonso L, Such E, Jimenez-Almazan J, Vidal E, Barragan E, Lopez-Pavia M, LLop M, Martin I, Gomez-Segui I, Montesinos P, Sanz MA, Dopazo J, Cervera J (2016) The mutational landscape of acute promyelocytic leukemia reveals an interacting network of cooccurrences and recurrent mutations. PLoS One 11(2): e0148346.

Iijima N, Goodwin EC, Dimaio D, Iwasaki A (2013) High-risk human papillomavirus E6 inhibits monocyte differentiation to Langerhans cells. Virology 444(1-2): 257-262.

Iqbal J, Nussenzweig A, Lubinski J, Byrski T, Eisen A, Bordeleau L, Tung NM, Manoukian S, Phelan CM, Sun P, Narod SA. Hereditary Breast Cancer Research Group (2016) The incidence of leukaemia in women with BRCA1 and BRCA2 mutations: an International Prospective Cohort Study. Br J Cancer 114(10): 1160-1164.

Kataoka K, Nagata Y, Kitanaka A, Shiraishi Y, Shimamura T, Yasunaga J, Totoki Y, Chiba K, Sato-Otsubo A, Nagae G, Ishii R, Muto S, Kotani S, Watatani Y, Takeda J, Sanada M, Tanaka H, Suzuki H, Sato Y, Shiozawa Y, Yoshizato T, Yoshida K, Makishima H, Iwanaga M, Ma G, Nosaka K, Hishizawa M, Itonaga H, Imaizumi Y, Munakata W, Ogasawara H, Sato T, Sasai K, Muramoto K, Penova M, Kawaguchi T, Nakamura H, Hama N, Shide K, Kubuki Y, Hidaka T, Kameda T, Nakamaki T, Ishiyama K, Miyawaki S, Yoon SS, Tobinai K, Miyazaki Y, Takaori-Kondo A, Matsuda F, Takeuchi K, Nureki O, Aburatani H, Watanabe T, Shibata T, Matsuoka M, Miyano S, Shimoda K, Ogawa S (2015) Integrated molecular analysis of adult $\mathrm{T}$ cell leukemia/lymphoma. Nat Genet 47(11): 1304-1315.

Lee BN, Follen M, Rodriquez G, Shen DY, Malpica A, Shearer WT, Reuben JM (2006) Deficiencies in myeloid antigen-presenting cells in women with cervical squamous intraepithelial lesions. Cancer 107(5): 999-1007.

Levin B, Lech D, Friedenson B (2012) Evidence that BRCA1- or BRCA2-associated cancers are not inevitable. Mol Med 18: 1327-1337.

Lewis CE, Pollard JW (2006) Distinct role of macrophages in different tumor microenvironments. Cancer Res 66(2): 605-612.

Morton LM, Dores GM, Tucker MA, Kim CJ, Onel K, Gilbert ES, Fraumeni Jr. JF, Curtis RE (2013) Evolving risk of therapy-related acute myeloid leukemia following cancer chemotherapy among adults in the United States, 1975-2008 Blood 121(15): 2996-3004.

Paz-y-Mino C, Ocampo L, Narvaez R, Narvaez L (1992) Chromosome fragility in lymphocytes of women with cervical uterine lesions produced by human papillomavirus. Cancer Genet Cytogenet 59(2): 173-176.

Salagovic J, Klimcakova L, Ilencikova D, Kafkova A (2012) Association of follicular lymphoma risk with BRCA2 N372H polymorphism in Slovak population. Med Oncol 29(2): 1173-1178.

Sanchez-Reyes K, Bravo-Cuellar A, Hernandez-Flores G, Lerma-Diaz JM, Jave-Suarez LF, Gomez-Lomeli P, de Celis R, Aguilar-Lemarroy A, Dominguez-Rodriguez JR, Ortiz-Lazareno PC (2014) Cervical cancer cell supernatants induce a phenotypic switch from U937-derived macrophageactivated M1 state into M2-like suppressor phenotype with change in toll-like receptor profile. Biomed Res Int 2014: 683068.

Scardocci A, Guidi F, D’Alo F, Gumiero D, Fabiani E, Diruscio A, Martini M, Larocca LM, Zollino M, Hohaus S, Leone G, Voso MT (2006) Reduced BRCA1 expression due to promoter hypermethylation in therapy-related acute myeloid leukaemia. Br J Cancer 95(8): 1108-1113.

Simoes PW, Medeiros LR, Simoes Pires PD, Edelweiss MI, Rosa DD, Silva FR, Silva BR, Rosa MI (2012) Prevalence of human papillomavirus in breast cancer: a systematic review. Int J Gynecol Cancer 22(3): 343-347.

Tummers B, Burg SH (2015) High-risk human papillomavirus targets crossroads in immune signaling. Viruses 7(5): 2485-2506.

Wagner JE, Tolar J, Levran O, Scholl T, Deffenbaugh A, Satagopan J, Ben-Porat L, Mah K, Batish SD, Kutler DI, MacMillan ML, Hanenberg H, Auerbach AD (2004) Germline mutations in BRCA2: shared genetic susceptibility to breast cancer, early onset leukemia, and Fanconi anemia. Blood 103(8): 3226-3229.

Zur Hausen H (2009) The search for infectious causes of human cancers: where and why. Virology 392(1): 1-10.

This work is published under the BJC's standard license to publish agreement. After 12 months the license terms will change to a Creative Commons AttributionNonCommercial-Share Alike 4.0 Unported License.

*Correspondence: Dr B Friedenson; E-mail: bernief@uic.edu

Published online 26 July 2016

(c) 2016 Cancer Research UK. All rights reserved 0007-0920/16 